\title{
Minor traumatic retroclival epidural haematoma in an adult
}

\author{
Toshihide Izumida, ${ }^{1}$ Kenichi Ogura ${ }^{2}$
}

${ }^{1}$ Toyama Kenritsu Chuo Byoin, Toyama, Japan

${ }^{2}$ Department of Emergency and Critical Care Center, Toyama Prefectural Central Hospital, Toyama, Japan

\section{Correspondence to} Dr Toshihide Izumida, m07011ti@jichi.ac.jp

Accepted 20 January 2017
CrossMark

To cite: Izumida T, Ogura K. BMJ Case Rep Published online: [please include Day Month Year] doi:10.1136/bcr-2016218063

\section{DESCRIPTION}

A man aged 64 years was transferred to the emergency department because of a witnessed syncopal event. It occurred after standing up and he hit the back of his head against the ground. On arrival, the result of his neurological examinations was normal. Brain CT revealed a hyperdense mass lesion. It extended from the posterior aspect of the dens to the upper clival region (figure 1). Blood tests, including coagulation, had no abnormal findings. Dynamic MRI, magnetic resonance angiography and digital subtraction angiography revealed no meningeal tumours, aneurysms, traumatic arterial dissections, and visible fractures or dislocations in the skull base or craniocervical region.

He was admitted for close neurological monitoring. On the 8th postadmission day, CT revealed no evidence of residual haematoma (figure 1). He was fully conscious with no headache, and he was discharged on that day.

Traumatic REDH is a rare reported entity. Most cases have been reported in children and have occurred after a motor vehicle accident involving hyperextension or hyperflexion injury of the neck. ${ }^{2}$ The pathophysiology of the formation of REDH is not fully understood. It is likely to be due to either dura stripping, ligament disruption or clivus fracture. ${ }^{3}$ The clinical course of REDH seems to be very benign. REDH can be treated conservatively in the absence of progressive neurological deterioration. ${ }^{1}$ To the best of our knowledge, this is the first minor traumatic REDH case in an adult.

\section{Learning points}

- The pathophysiology of the formation of REDH is not fully understood. It is likely due to either dura stripping, ligament disruption or clivus fracture.

- Traumatic REDH should be considered when hyperflexion or hyperextension injury of the neck occurs, regardless of the severity of the injury.

- The clinical course of REDH seems to be very benign. REDH can be treated conservatively.

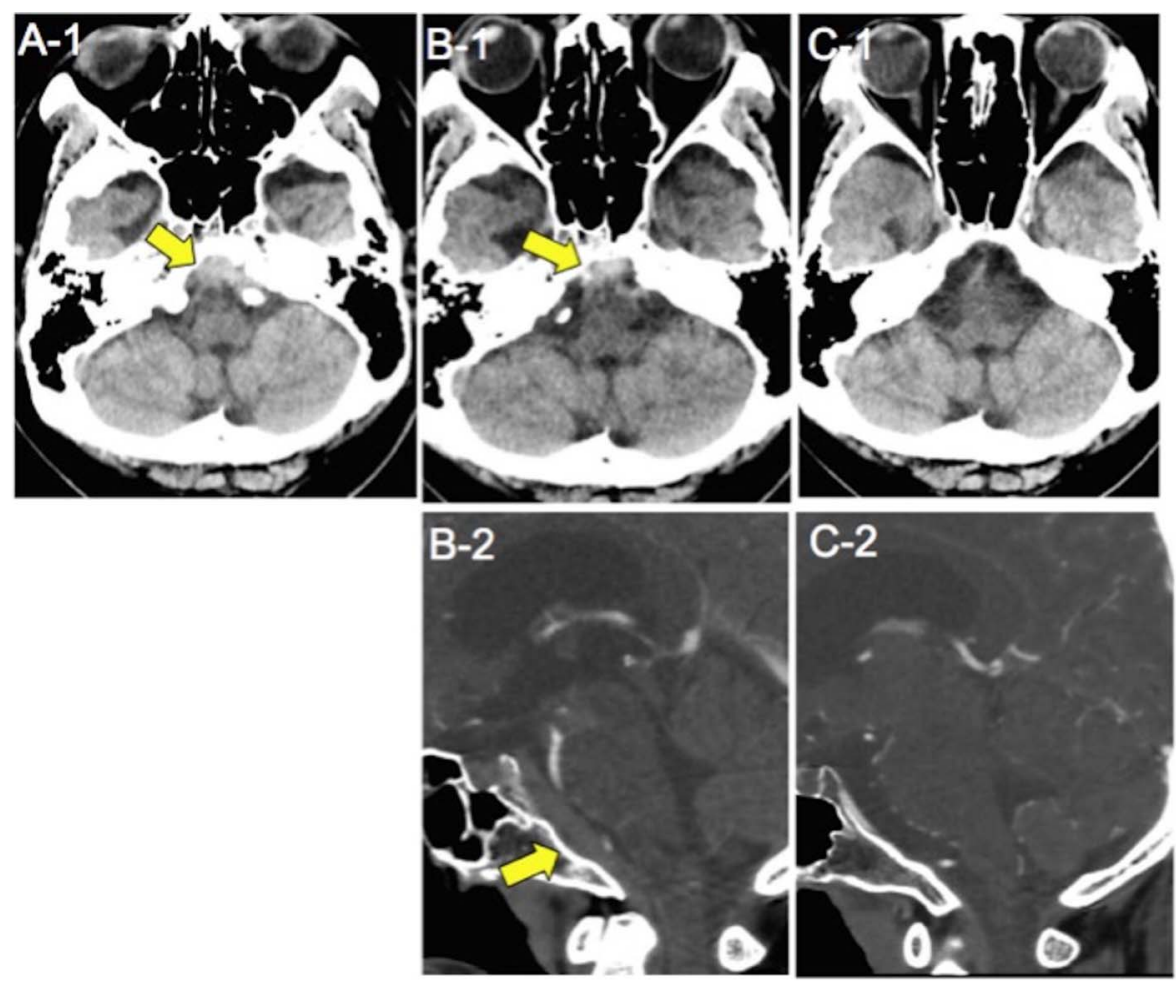

Figure 1 Brain $\mathrm{CT}$ of the present patient showing gradual decrease in the retroclival epidural haematoma: CT taken initially (A), 2 hours later (B) and 8 days after the accident (C). 
Competing interests None declared.

\section{Patient consent Obtained.}

Provenance and peer review Not commissioned; externally peer reviewed.

\section{REFERENCES}

1 Kwon TH, Joy H, Park YK, et al. Traumatic retroclival epidural hematoma in a child: case report. Neurol Med Chir (Tokyo) 2008;48:347-50.
2 Ratilal B, Castanho P, Vara Luiz C, et al. Traumatic clivus epidural hematoma: case report and review of the literature. Surg Neurol 2006;66:200-2.

3 Guillaume D, Menezes AH. Retroclival hematoma in the pediatric population. Report of two cases and review of the literature. J Neurosurg 2006;105: 321-5.

Copyright 2017 BMJ Publishing Group. All rights reserved. For permission to reuse any of this content visit http://group.bmj.com/group/rights-licensing/permissions.

BMJ Case Report Fellows may re-use this article for personal use and teaching without any further permission.

Become a Fellow of BMJ Case Reports today and you can:

- Submit as many cases as you like

- Enjoy fast sympathetic peer review and rapid publication of accepted articles

- Access all the published articles

- Re-use any of the published material for personal use and teaching without further permission

For information on Institutional Fellowships contact consortiasales@bmjgroup.com

Visit casereports.bmj.com for more articles like this and to become a Fellow 